\title{
Development of Eulophidae (Hymenoptera) parasitoids in Diatraea saccharalis (Lepidoptera: Crambidae) pupae exposed to entomopathogenic fungi
}

\author{
C. Rossoni, ${ }^{1}$ F.F. Pereira, S.O. Kassab, A. Rodrigues, R.H. Barbosa, J.C. Zanuncio
}

\begin{abstract}
Palmistichus elaeisis Delvare and LaSalle, Tetrastichus howardi (Olliff), and Trichospilus diatraeae Cherian and Margabandhu (Hymenoptera: Eulophidae) are promising candidates for the control of sugarcane borer, Diatraea saccharalis (Fabricius) (Lepidoptera: Crambidae). The fungi Beauveria bassiana (Balsamo) Vuillemin (Cordycipitaceae) and Metarhizium anisopliae (Metchnikoff) Sorokin (Clavicipitaceae) also can be used to control sugarcane borers plus leafhoppers (Hemiptera: Cercopidae) in sugarcane. This observation motivated us to investigate whether entomopathogenic fungi can affect biological aspects of these parasitoids. Diatraea saccharalis pupae ( 24 hours in age) were exposed to parasitism by three females of each eulophid species for 72 hours and then placed in small tubes. A contact surface treated with $1 \mathrm{~mL}$ of fungal suspension was placed inside each tube with the parasitised pupae at concentrations of $1 \times 10^{9}, 5 \times 10^{9}$, or $10 \times 10^{9}$ conidia $\mathrm{mL}^{-1}$ of $M$. anisopliae and B. bassiana. Exposure to fungi reduced emergence of adult $P$. elaeisis, but not of $T$. howardi and $T$. diatraeae. Life cycle duration, progeny, and sex ratio of $P$. elaeisis were not affected by exposure. Exposure was associated with decreased longevity for both sexes of $T$. howardi and in males of P. elaeisis, but not at levels expected to affect their performance as biocontrol agents. In general, the exposure of eulophid species developing in pupae of $D$. saccharalis exposed to entomopathogenic fungi, did not compromise the biological aspects of these parasitoids.
\end{abstract}

\section{Introduction}

Brazil is the world's largest producer of sugarcane (Kassab et al. 2015). The main pests affecting this crop are the sugarcane borer, Diatraea saccharalis (Fabricius) (Lepidoptera: Crambidae), and the leafhopper Mahanarva fimbriolata (Stål) (Hemiptera: Cercopidae) (Kassab et al. 2014; Rossoni et al. 2014a, 2014b). The direct damage caused by $D$. saccharalis can lead to loss of biomass and death of apical buds in sugarcane plants (Dinardo-Miranda et al. 2011, 2012). Indirect effects include the reduced production of sugar and alcohol, due to the presence of microorganisms in the affected stems (Simões et al. 2012; Rossato et al. 2013).

Chemical insecticides are inefficient in controlling D. saccharalis, because the first instars feed on the cartridge leaves and subsequently migrate to the sugarcane stalk where they are protected from topical applied insecticides (Antigo et al. 2013; Oliveira et al. 2013). This has led to research on biological methods to control of this pest (Rodrigues et al. 2013).

Diatraea saccharalis is attacked by a large number of micro-Hymenoptera and several species of fungi, of particular importance are the parasitoids Palmistichus elaeisis Delvare and LaSalle, Tetrastichus howardi (Olliff), and Trichospilus diatraeae Cherian and Margabandhu, (Hymenoptera: Eulophidae) (Cruz et al. 2011; Chicera et al. 2012; Vargas et al. 2014; Pereira et al. 2015). The entomopathogenic fungi Beauveria bassiana (Balsamo) Vuillemin (Cordycipitaceae) and Metarhizium anisopliae (Metchnikoff) Sorokin

Received 22 October 2015. Accepted 18 January 2016. First published online 2 May 2016.

C. Rossoni, ${ }^{1}$ F.F. Pereira, A. Rodrigues, Faculdade de Ciências Biológicas e Ambientais, Universidade Federal da Grande Dourados, 79.804-970, Dourados, Mato Grosso do Sul, Brazil

S.O. Kassab, R.H. Barbosa, Faculdade de Ciências Agrárias, Universidade Federal da Grande Dourados, 79.804-970, Dourados, Mato Grosso do Sul, Brazil

J.C. Zanuncio, Departamento de Fitotecnia, Universidade Federal de Viçosa, 36570-900, Viçosa, Minas Gerais, Brazil

${ }^{1}$ Corresponding author (e-mail: camilasrossoni@gmail.com).

Subject editor: Jianghua Sun

doi:10.4039/tce.2016.15 
(Clavicipitaceae) also can provide significant levels of control. For example, M. anisopliae is produced in rice and applied to sugar cane fields in Brazil to reduce populations of M. fimbriolata (Loureiro et al. 2005).

Concurrent use of these fungi and parasitoids might work in a synergistic or antagonistic manner (Roy and Cottrell 2008) to enhance control D. saccharalis, but further research is required to clarify the nature of their interactions when co-occurring in the same host (Santos et al. 2006; Rossoni et al. 2014a, 2014b; Ibrahim 2015). This fact motivated us to investigate whether B. bassiana and $M$. anisopliae compromise the development of P. elaeisis, T. howardi, and $T$. diatraeae in pupae of $D$. saccharalis. Specifically, we assessed the effect of exposure to these fungi on the percentage of hosts from which parasitoids emerged, the number of parasitoids emerging per pupa, egg-to-adult development time, sex ratio, and adult longevity.

\section{Materials and methods}

Experimental work was conducted in the Biological Control of Insects (LECOBIOL) and Microbiology Laboratories of the Universidade Federal da Grande Dourados (UFGD) in Dourados, Mato Grosso do Sul, Brazil.

\section{Source of fungi and insects}

The formulations of fungi used in the experiment were the commercial products Metie $\mathrm{WP}^{\circledR}$ (M. anisopliae - IBCB 425) and Ballvéria $\mathrm{WP}^{\circledR}$ (B. bassiana - IBCB 66) provided by the company Ballagro Agro Tecnologia (Atibaia, São Paulo, Brazil). Both formulations had more than 95\% spore viability.

Diatraea saccharalis eggs were obtained from laboratory colonies maintained by LECOBIOL (UFGD). Eggs were packed into glass vials $(8.5 \mathrm{~cm}$ diameter $\times 13 \mathrm{~cm}$ height $)$ containing an artificial diet based on wheat germ $(150 \mathrm{~g})$, soybean $(540 \mathrm{~g})$, and the phagostimulant, sugarcane yeast $(450 \mathrm{~g})$ (Saccharomyces cerevisiae Meyen ex Hansen; Saccaromycetales: Saccaromycetaceae) to provide nutrition for the newly hatched larvae that remained in situ until the final instar was reached (Parra 2007). Larvae were then transferred to disposable Petri dishes
( $6.5 \mathrm{~cm}$ diameter $\times 2.5 \mathrm{~cm}$ height $)$ with a feedback diet based on soya bean and sugarcane yeast until the formation of pupae was observed. Pupae were collected and placed in clear plastic pots (rectangular, $500 \mathrm{~mL}, 14.2 \times 9.8 \times 4.7 \mathrm{~cm}$ ) where they remained until adult emergence. The adults were sexed and 50 adults (30 males and 20 females) were placed in polyvinyl-chloride-tube cages $(10 \mathrm{~cm}$ diameter $\times 22 \mathrm{~cm}$ height $)$, internally coated with bond paper for harvesting eggs. The cages were closed with bond paper and elastic. Eggs were collected daily, washed with a solution of copper sulfate $(1 \%)$, and stored in a climatic chamber at $25 \pm 2{ }^{\circ} \mathrm{C}, \quad 70 \pm 10 \%$ relative humidity, and 14:10 hours light:dark cycle, a methodology adapted from Parra (2007).

Populations of P. elaeisis, T. howardi, and T. diatraeae were maintained separately in glass tubes $(2.5 \mathrm{~cm}$ diameter $\times 8.5 \mathrm{~cm}$ height) sealed with cotton, and fed with droplets of pure honey. To propagate these species, pupae of $D$. saccharalis (24-48 hours old) were exposed to female parasitoids. The parasitised pupae were individually placed in glass tubes and maintained at $25 \pm 2{ }^{\circ} \mathrm{C}$, $70 \pm 10 \%$ relative humidity, and 14:10 light:dark hours until the emergence of adults (Vargas et al. 2011; Chichera et al. 2012).

\section{Experimental development}

For each parasitoid species, pupae of $D$. saccharalis (24 hours old) were exposed to parasitism by three females over 72 hours. Females were 24 hours in age for T. howardi (Pereira et al. 2015) and T. diatraeae (Pastori et al. 2013), and 72 hours in age for $P$. elaeisis (Andrade et al. 2012). These ages were selected to optimise the abundance of oocytes. After exposure, the pupae were placed in individual glass tubes $(1.5 \mathrm{~cm}$ diameter $\times 10 \mathrm{~cm}$ height) and capped with hydrophilic cotton.

A piece of filter paper $(1 \times 9 \mathrm{~cm})$ either untreated (control) or treated with $1 \mathrm{~mL}$ of fungal suspension was placed inside with the parasitised pupae each tube for 96 hours (Rossoni et al. $2014 \mathrm{a}, 2014 \mathrm{~b})$ at concentrations of $1 \times 10^{9}$, $5 \times 10^{9}$, and $10 \times 10^{9}$ con $\mathrm{mL}^{-1}$ of Metiê $\hat{~}^{\circledR}$ (M. anisopliae) and Ballvéria ${ }^{\circledR}(B$. bassiana). The tubes were incubated in a growth chamber (BOD) at $25 \pm 2{ }^{\circ} \mathrm{C}, 14: 10$ hour light:dark cycle, and $70 \pm 10 \%$ relative humidity until the emergence of parasitoids. The filter papers remained in the tubes 
for a period of 96 hours before removal. Thus, for each parasitoid species, data was collected for six treatments and a control, replicated 10 times (five parasitised pupae), totaling 50 pupae per treatment.

To measure the effect of fungi exposure on parasitoid fitness, data were recorded for percentage of exposed pupae with adult parasitoid emergence, the number of parasitoids emerging per pupa, and development time (the number of days from date of pupa exposure until emergence of adult parasitoids). Data also were recorded for the frequency of female progeny and the longevity of adult parasitoids. This latter assessment was measured for, 20 females and 20 males of each species of parasitoid, randomly selected for each treatment.

\section{Statistical analyses}

To test for an effect of fungi exposure, separate Scott-Knott tests (critical $P=0.05$ ) were performed using percentage emergence, number of progeny, developmental time, female frequency, and adult longevity as dependent variables, with treatment as the independent variable. These tests were performed for each combination of fungi and parasitoids. Comparisons were not made across species, because differences in natural history could potentially confound the interpretation of the data.

\section{Results}

Fitness parameters for the three parasitoid species developing in pupae exposed to the different concentrations of $B$. bassiana and M. anisopliae are reported in Table 1 .

The emergence of $T$. howardi and $T$. diatraeae from pupae was not affected $(P>0.05)$ by fungal exposure. The emergence of the parasitoid $P$. elaeisis was affected $(P=0.01)$, with values ranging from $67 \%$ to $98 \%$. Development time, progeny, and the female frequency of $P$. elaeisis were not affected by fungal exposure $(P<0.05)$. Adult longevity values for $P$. elaeisis females did not differ among treatments, but the values for males ranged from $9.95 \pm 1.01$ to $14.80 \pm 0.29$ days.

The development time of $T$. howardi ranged from $17.54 \pm 0.19$ to $18.28 \pm 0.18$ days, which may be related to the natural history of this parasitoid. The number of progeny of $T$. howardi emerging from pupae ranged $123.80 \pm 2.44$ to $146.82 \pm 2.84$ days, the highest value being that of the control. The female frequency of $T$. howardi ranged from $0.82 \pm 0.05$ to $0.92 \pm 0.09$ for all treatments. The longevity of males and females of T. howardi was affected by treatment, with values ranging from $8.80 \pm 0.53$ to $19.95 \pm 0.78$ days.

The development time of $T$. diatraeae was affected by treatments $(P=0.01)$, and ranged from $17.80 \pm 1.74$ to $19.30 \pm 0.06$ days. The number of progeny of $T$. diatraeae emerging from pupae of exposed to fungal treatments ranged from $283.10 \pm 2.8$ to $307.66 \pm 2.89$. The frequency of females for $T$. diatraeae ranged from $0.90 \pm 0.08$ to $0.93 \pm 0.19$ across different fungal treatments. The longevity of $T$. diatraeae males and females did not differ among treatments.

\section{Discussion}

The negligible variations in emergence of T. howardi and T. diatraeae from hosts in contact with $B$. bassiana and $M$. anisopliae fungi suggest that the exposure of parasitised pupae to the biopesticides did not affect parasitoid fitness. This observation has been demonstrated in the parasitoids Trichogramma galloi Zucchi (Hymenoptera: Trichogrammatidae) in $D$. saccharalis eggs treated with isolated IPA 159E (Broglio-Micheletti et al. 2006) and in Cotesia flavipes (Cameron) (Hymenoptera: Braconidae) exposed to the microbial insecticides Biometha WP Plus ${ }^{\circledR} \quad(M$. anisopliae $)$ Biovéria $\mathrm{G}^{\circledR}$ (B. bassiana), Metarril WP ${ }^{\circledR}$ (M. anisopliae), Boverril WP ${ }^{\circledR}$ (B. bassiana), and Metiê $\mathrm{WP}^{\circledR}$ (M. anisopliae) (Rossoni et al. 2014a, 2014b). The parasitoids Psyttalia concolor (Szépligeti) and Psyttalia cosyrae (Wilkinson) (Hymenoptera: Braconidae) successfully emerged from Ceratitis capitata (Weidemann) and Ceratitis cosyra (Walker) (Diptera: Tephritidae) exposed to M. anisopliae in treated soil at 0 and 183 days after treatment application, indicating that the fungus did not exert an adverse effect on their development (Ekesi et al. 2005). Similar results were observed for the parasitoid Phradis morionellus (Holmgren) (Hymenoptera: Ichneumonidae) developing in Meligethes aeneus (Fabricius) (Coleoptera: Nitidulidae); i.e., M. anisopliae was shown to be effective in controlling the pest beetle, 
Table 1. Biological aspects of Eulophidae parasitoids that emerged from pupae of Diatraea saccharalis (Lepidoptera: Crambidae) following exposure to various concentrations of Beauveria bassiana (Cordycipitaceae) and Metarhizium anisopliae (Clavicipitaceae).*

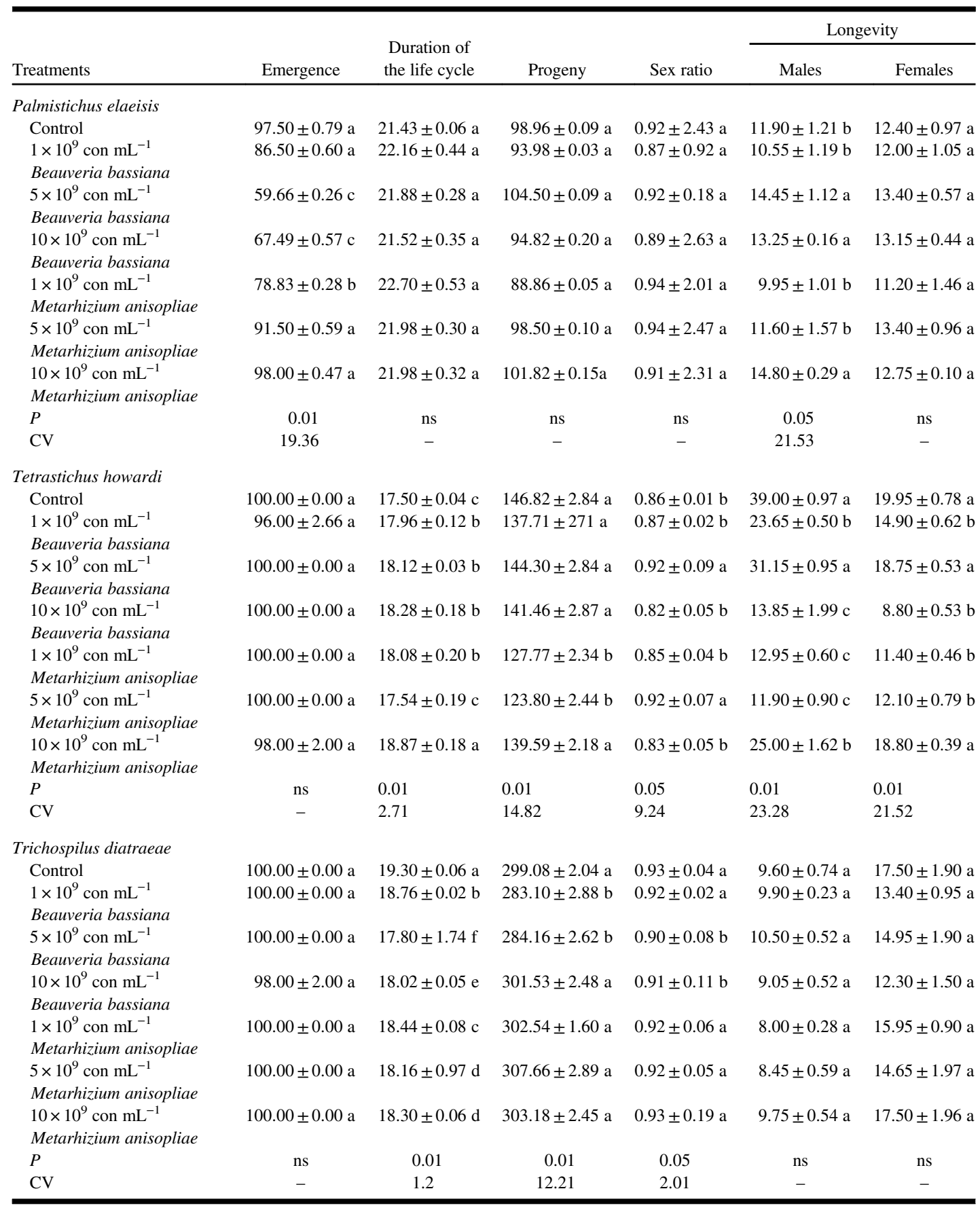

\section{Notes:}

* Means followed by the same letter do not differ by the Scott-Knott test, with up to 5\% probability.

con $\mathrm{mL}^{-1}$, conidia of B. bassiana and/or M. anisopliae per $\mathrm{mL} ; \mathrm{CV}$, coefficient of variation. 
but did not affect the development of the parasitoid (Husberg and Hokkanen 2001).

Emergence of female $P$. elaeisis was reduced with exposure $B$. bassiana and $M$. anisopliae, but development time, number of progeny, and female frequency were not affected. A similar result was observed for $C$. flavipes following exposure to these fungi (Rossoni et al. 2014a, 2014b). In certain instances, parasitoids may be susceptible to infection by entomopathogenic fungi, but can still reproduce, thus, fungi and parasites can be applied simultaneously for pest control (Nielsen et al. 2005).

Development times of $T$. howardi and $T$. diatraeae in hosts exposed to fungi were affected, but the variation across treatments was small, i.e., 1.28 days for $T$. diatraeae and 0.78 days for T. howardi. This suggests that the observed variation was unrelated to treatment and maybe attributed to natural history. This, observation has been reported for these parasitoids in research conducted by Vargas et al. (2011), Rodrigues et al. (2013), Costa et al. (2014a, 2014b), Glaeser et al. (2014), and Pereira et al. (2015). These results differ from those found in Aphidius colemani (Viereck) (Hymenoptera: Braconidae), which displayed a decreased development time when its host, Myzus persicae (Sulzer) (Hemiptera: Aphididae), was treated with a suspension of B. bassiana (Emami et al. 2013).

The number of progeny for T. howardi and $T$. diatraeae emerging from pupae was affected by treatment, but this maybe due to other factors. Previous research has indicated that the numbers of produced maybe related to the quantity of eggs and toxins deposited during egg laying by the female parasitoid, the immune response of the host, and host biomass (Andrade et al. 2010; Cusumano et al. 2010; Harvey et al. 2013). Inadequate doses of toxins injected by female parasitoid may reduce numbers of progeny emerging from the host (Cusumano et al. 2010; Harvey et al. 2013). Host hemocytes can encapsulate the eggs and larvae of parasitoids to reduce parasitoid emergence (Strand 2008; Andrade et al. 2010). Variations in host biomass also can affect parasitoid propagation, as shown for $T$. diatraeae in pupae of D. saccharalis (Glaeser 2011).

The frequency of female progeny for $P$. elaeisis, T. howardi, and $T$. diatraeae was not predictably affected by treatment, suggesting that host exposure to fungi did not affect sex ratio. Frequency exceeded $0.82 ; 0.50$ is the minimum value required by quality control processes (Navarro 1998). This high female bias increases the efficiency of parasitism in field releases, because females are responsible for subsequent generations (Rodrigues et al. 2013; Costa et al. 2014a, 2014b; Barbosa et al. 2015). For example, a low frequency of females has been shown can to compromise the parasitism efficiency of parasitoids (Pereira et al. 2009a, 2009b, 2010, 2011). We therefore propose that the changes in sex ratio of Eulophidae within pupae observed in this experiment can be attributed to the availability of host resources, as reported for $T$. diatraeae in pupae of D. saccharalis and Tenebrio molitor Linnaeus (Coleoptera: Tenebrionidae) (Chichera et al. 2012; Favero et al. 2013, 2014), P. elaeisis in pupae of Anticarsia gemmatalis Hübner (Lepidoptera: Erebidae), Bombyx mori Linnaeus (Lepidoptera: Bombycidae), and $D$. saccharalis (Pereira et al. 2009a, 2009b, 2010, 2013; Chichera et al. 2012), and T. howardi in pupae of D. saccharalis (Vargas et al. 2011; Costa et al. 2014a; Pereira et al. 2015) and Erinnyis ello (Linnaeus) (Lepidoptera: Sphingidae) (Barbosa et al. 2015).

The longevity of females of $P$. elaeisis and $T$. diatraeae emerging from pupae was not affected by treatment. However, a decreased longevity was observed in both sexes of $T$. howardi and in males of $P$. elaeisis. It has previously been suggested that this biological characteristic correlates positively with increased parasitism in field conditions (Pratissoli et al. 2007). Thereby, a greater longevity can increase the search and parasitism capabilities of parasitoid females, contributing to the reduction of the pest population and an increased effectiveness in controlling outbreaks. However, we believe that the reduction of this biological feature in $T$. howardi and P. elaeisis was insufficient do compromise the propagation and parasitism of these parasitoids.

In general, the exposure of pupae parasitised by $P$. elaeisis, $T$. howardi, and $T$. diatraeae to entomopathogenic fungi did not affect the development or biological characteristics of these parasitoids. This observation is important, given that, entomopathogens can come into contact with pupae parasitised by these species under field conditions. Because, these biological characteristics (emergence, duration of life cycle, progeny, and sex ratio) are correlated with the biological qualities of 
parasitoids, we propose that use of these parasitoid species is compatible with the entomopathogenic fungi B. bassiana and M. anisopliae.

\section{Acknowledgements}

To the Brazilian institutions, Coordenação de Aperfeiçoamento de Pessoal de Nível Superior (CAPES) for granting the scholarship, Fundação de Amparo à Pesquisa do Estado de Minas Gerais (FAPEMIG), and Conselho Nacional de Desenvolvimento Cientifico e Tecnológico (CNPq) for funding the project approved by the Chamada Universal 14/2012-Faixa A (process CNPq number 482174/2012-9).

\section{References}

Andrade, G.S., Serrão, J.E., Zanuncio, J.C., Zanuncio, T.V., Leite, G.L.D., and Polanczyk, R.A. 2010. Immunity of an alternative host can be overcome by higher densities of its parasitoids Palmistichus elaeisis and Trichospilus diatraeae. Public Library of Science One, 5: 1-7.

Andrade, G.S., Sousa, A.H., Santos, J.C., Gama, F.C., Serrão, J.E., and Zanuncio, J.C. 2012. Oogenesis pattern and type of ovariole of the parasitoid Palmistichus elaeisis (Hymenoptera: Eulophidae). Anais da Academia Brasileira de Ciências, 84: 767-774.

Antigo, M.R., Oliveira, H.N., Carvalho, G.A., and Pereira, F.F. 2013. Repelência de produtos fitossanitários usados na cana-de-açúcar e seus efeitos na emergência de Trichogramma galloi. Revista Ciência Agronômica, 44: 910-916.

Barbosa, R.H., Kassab, S.O., Pereira, F.F., Rossoni, C., Costa, D.P., and Berndt, M.A. 2015. Parasitism and biological aspects of Tetrastichus howardi (Hymenoptera: Eulophidae) on Erinnyis ello (Lepidoptera: Sphingidae) pupae. Ciência Rural, 45: 185-188.

Broglio-Micheletti, S.M.F., Santos, A.J.N., and Pereira-Barros, J.L. 2006. Ação de alguns produtos fitossanitários para adultos de Trichogramma galloi Zucchi, 1988 (Hymenoptera: Trichogrammatidae). Ciência e Agrotecnologia, 30: 1051-1055.

Chichera, R.A., Pereira, F.F., Kassab, S.O., Barbosa, R.H., Pastori, P.L., and Rossoni, C. 2012. Capacidade de busca e reprodução de Trichospilus diatraeae e Palmistichus elaeisis (Hymenoptera: Eulophidae) em pupas de Diatraea saccharalis (Lepidoptera: Crambidae). Interciência, 37: 852-856.

Costa, D.P., Pereira, F.F., Kassab, S.O., Rossoni, C., Favero, K., and Barbosa, R.H. 2014a. Reprodução de Tetrastichus howardi (Hymenoptera: Eulophidae) em pupas de Diatraea saccharalis (Lepidoptera: Crambidae) de diferentes idades. Revista de Ciências Agrárias/Amazonian Journal of Agricultural and Environmental Sciences, 57: 67-71.
Costa, D.P., Pereira, F.F., Kassab, S.O., Rossoni, C., Pastori, P.L., and Zanuncio, J.C. 2014b. Tetrastichus howardi (Hymenoptera: Eulophidae) in different densities and periods of parasitism on Diatraea saccharalis (Lepidoptera: Crambidae) caterpillars. Annals of the Entomological Society of America, 107: 961-966.

Cruz, I., Redoan, A.C., Silva, R.B., Figueiredo, M.L.C., and Penteado-Dias, A.M. 2011. New record of Tetrastichus howardi (Olliff) as a parasitoid of Diatraea saccharalis (Fabr.) on maize. Scientia Agricola, 68: 252-254.

Cusumano, A., Peri, E., Bradleigh, V.S., and Colazza, S. 2010. Interspecific extrinsic and intrinsic competitive interactions in egg parasitoids. Biological Control, 57: 719-734.

Dinardo-Miranda, L.L., Anjos, I.A., Costa, V.P., and Fracasso, J.V. 2012. Resistance of sugarcane cultivars to Diatraea saccharalis. Pesquisa Agropecuária Brasileira, 47: 1-7.

Dinardo-Miranda, L.L., Fracasso, J.V., and Perecin, D. 2011. Variabilidade espacial de populações de Diatraea saccharalis em canaviais e sugestão de método de amostragem. Bragantia, 70: 577-585.

Ekesi, S., Maniania, N.K., Mohamed, S.A., and Lux, S.A. 2005. Effect of soil application of different formulations of Metarhizium anisopliae on African tephritid fruit flies and their associated endoparasitoids. Biological Control, 35: 83-91.

Emami, F., Alichi, M., and Minaei, K. 2013. Interaction between the entomopathogenic fungus, Beauveria bassiana (Ascomycota: Hypocreales) and the parasitoid wasp, Aphidius colemani Viereck (Hymenoptera: Braconidae). Journal of Entomological and Acarological Research, 45: e4.

Favero, K., Pereira, F.F., Kassab, S.O., Costa, D.P., and Zanuncio, J.C. 2014. Life and fertility tables of Trichospilus diatraeae (Hymenoptera: Eulophidae) with Tenebrio molitor (Coleoptera: Tenebrionidae) pupae. Annals of the Entomological Society of America, 107: 621-626.

Favero, K., Pereira, F.F., Kassab, S.O., Oliveira, H.N., Costa, D.P., and Zanuncio, J.C. 2013. Biological characteristics of Trichospilus diatraeae (Hymenoptera: Eulophidae) are influenced by the number of females exposed per pupa of Tenebrio molitor (Coleoptera: Tenebrionidae). Florida Entomologist, 96: 583-589.

Glaeser, D.F. 2011. Características biológicas e comportamentais de Trichospilus diatraeae (Hymenoptera: Eulophidae) criado em pupa de Diatraea saccharalis (Lepidoptera: Crambidae). PhD Thesis in Agronomy, Universidade Federal da Grande Dourados, Dourados, Mato Grosso do Sul, Brazil. Available from http://200.129.209.183/arquivos/arquivos/ 78/MESTRADO-DOUTORADO-AGRONOMIA/ Tese\%20\%20Daniele\%20Fabiana\%20Glaeser.pdf [accessed 19 March 2016]. 
Glaeser, D.F., Pereira, F.F., Vargas, E.L., Calado, V.R.F., and Favero, K. 2014. Desempenho reprodutivo de Trichospilus diatraeae no hospedeiro natural Diatraea saccharalis três gerações no hospedeiro alternativo Tenebrio molitor. Pesquisa Agropecuária Tropical, 44: 213-218.

Harvey, J.A., Poelman, E.H., and Tanaka, T. 2013. Intrinsic inter and intraspecific competition in parasitoid wasps. Annual Review of Entomology, 58: 333-351.

Husberg, G.B. and Hokkanen, H.M.T. 2001. Effects of Metarhizium anisopliae on the pollen beetle Meligethes aeneus and its parasitoids Phradis morionellus and Diospilus capito. BioControl, 46: 261-273.

Ibrahim, R.A. 2015. Can entomopathogenic fungi clearly differentiate between harmful and beneficial insects in nature? African Entomology, 23: 486-493.

Kassab, S.O., Loureiro, E.S., Rossoni, C., Pereira, F.F., Barbosa, R.H., Costa, D.P., and Zanuncio, J.C. 2014. Combinations of Metarhizium anisopliae with chemical insecticides and their effectiveness in Mahanarva fimbriolata (Hemiptera: Cercopidae) control on sugarcane. Florida Entomologist, 97: 146-154.

Kassab, S.O., Loureiro, E.S., Rossoni, C., Pereira, F.F., Mota, T.A., Barbosa, R.H., and Costa, D.P. 2015. Control of Mahanarva fimbriolata (Stal) (Hemiptera: Cercopidae) with entomopathogenic fungus and insecticides using two sampling methods on sugarcane fields. African Journal of Agricultural Research, 10: 803-810.

Loureiro, E.S., Batista Filho, A., Almeida, J.E.M., and Pessoa, L.G.A. 2005. Seleção de isolados de Metarhizium anisopliae (Metch.) Sorok. contra a cigarrinha da raiz da cana-de-açúcar Mahanarva fimbriolata (Stål) (Hemiptera: Cercopidae) em laboratório. Neotropical Entomology, 34: 791-798.

Navarro, M.A. 1998. Trichogramma spp. procucción, uso y manejo en Colombia. Imprectec, Guadalajara de Buga, Colombia.

Nielsen, C., Skovgård, H., and Steenberg, T. 2005. Effect of Metarhizium anisopliae (Deuteromycotina: Hyphomycetes) on survival and reproduction of the filth fly parasitoid, Spalangia cameroni (Hymenoptera: Pteromalidae). Environmental Entomology, 34: 133-139.

Oliveira, H.N., Antigo, M.R., Carvalho, G.A., Glaeser, D.F., and Pereira, F.F. 2013. Seletividade de inseticidas utilizados na cana-de-açúcar a adultos de Trichogramma galloi Zucchi (Hymenoptera: Trichogrammatidae). Bioscience Journal, 29: 1267-1274.

Parra, J.R.P. 2007. Técnicas de criação de insetos para programa de controle biológico. $6^{\mathrm{a}}$ edição. Editora Esalq/Fealq, Piracicaba, Brazil.

Pastori, P.L., Zanuncio, J.C., Pereira, F.F., Pratissoli, D., Cecon, P.R., and Serrão, J.E. 2013. Temperatura e tempo de refrigeração de pupas de Anticarsia gemmatalis (Lepidoptera: Noctuidae) afetam parâmetros biológicos de Trischospilus diatraeae (Hymenoptera: Eulophidae)? Semina: Ciências Agrárias, 34: 1493-1508.
Pereira, F.F., Kassab, S.O., Calado, V.R.F., Vargas, E.L., Oliveira, H.N., and Zanuncio, J.C. 2015. Parasitism and emergence of Tetrastichus howardi (Hymenoptera: Eulophidae) on Diatraea saccharalis (Lepidoptera: Crambidae) larvae, pupae and adults. Florida Entomologist, 98: 377-380.

Pereira, F.F., Zanuncio, J.C., Kassab, S.O., Pastori, P.L., Barbosa, R.H., and Rossoni, C. 2013. Biological characteristics of Palmistichus elaeisis Delvare \& Lasalle (Hymenoptera: Eulophidae) on refrigerated pupae of Anticarsia gemmatalis Hubner (Lepidoptera: Noctuidae). Chilean Journal of Agricultural Research, 73: 08-09.

Pereira, F.F., Zanuncio, J.C., Oliveira, H.N., Grance, E.V., Pastori, P.L., and Gava-Oliveira, M.D. 2011. Thermal requirements and estimate number of generations of Palmistichus elaeisis (Hymenoptera: Eulophidae) in different Eucalyptus plantations regions. Brazilian Journal of Biology, 71: 431-436.

Pereira, F.F., Zanuncio, J.C., Pastori, P.L., Chichera, R.A., Andrade, G.S., and Serrão, J.E. 2010. Reproductive biology of Palmistichus elaeisis (Hymenoptera: Eulophidae) with alternative and natural hosts. Zoologia, 27: 887-891.

Pereira, F.F., Zanuncio, J.C., Serrão, J.E., Oliveira, H.N., Favero, K., and Grance, E.L.V. 2009a. Progênie de Palmistichus elaeisis Delvare \& LaSalle (Hymenoptera: Eulophidae) parasitando pupas de Bombyx mori L. (Lepidoptera: Bombycidae) de diferentes idades. Neotropical Entomology, 38: 660-664.

Pereira, F.F., Zanuncio, J.C., Serrão, J.E., Patrick, L.P., and Ramalho, F.S. 2009b. Reproductive performance of Palmistichus elaeisis Delvare and LaSalle (Hymenoptera: Eulophidae) with previously refrigerated pupae of Bombyx mori (Lepidoptera: Bombycidae). Brazilian Journal of Biology, 69: 631-637.

Pratissoli, D., Polanczyk, R.A., Pereira, C.L.T., Furtado, I.S.A., and Cocheto, J.G. 2007. Influência da fase embrionária dos ovos da traça-das-crucíferas sobre fêmeas de Trichogramma pretiosum com diferentes idades. Horticultura Brasileira, 25: 286-290.

Rodrigues, M.A.T., Pereira, F.F., Kassab, S.O., Pastori, P.L., Glaeser, D.F., Oliveira, H.N., and Zanuncio, J.C. 2013. Thermal requirements and generation estimates of Trichospilus diatraeae (Hymenoptera: Eulophidae) in sugarcane producing regions of Brasil. Florida Entomologist, 96: 154-159.

Rossato, J.A.S., Costa, G.H.G., Madaleno, L.L., Mutton, M.J.R., Higley, L.G., and Fernandes, O.A. 2013. Characterization and impact of the sugarcane borer on sugarcane yield and quality. Agronomy Journal, 105: 643-648.

Rossoni, C., Kassab, S.O., Loureiro, E.S., Pereira, F.F., Costa, D.P., Barbosa, R.H., and Zanuncio, J.C. 2014a. Metarhizium anisopliae and Beauveria bassiana (Hypocreales: Clavicipitaceae) are compatible with Cotesia flavipes (Hymenoptera: Braconidae). Florida Entomologist, 97: 1794-1804. 
Rossoni, C., Loureiro, E.S., Pereira, F.F., Kassab, S.O., Costa, D.P., and Barbosa, R.H. 2014b. Selectivity of Metarhizium anisopliae and Beauveria bassiana (Hypocreales: Clavicipitaceae) on adults of Cotesia flavipes (Hymenoptera: Braconidae). Folia Biologica (Kraków), 62: 269-275.

Roy, H.E. and Cottrell, E. 2008. Forgotten natural enemies: interactions between coccinellids and insect-parasitic fungi. European Journal of Entomology, 105: 391-398.

Santos, H.J.G., Marques, E.J., Barros, R., and Gondim, M.G.C. 2006. Interação de Metarhizium anisopliae (Metsch.) Sorok., Beauveria bassiana (Bals.) Vuill. e o parasitoide Oomyzus sokolowskii (Kurdjumov) (Hymenoptera: Eulophidae) sobre larvas da traçadas-crucíferas, Plutella xylostella (L.) (Lepidoptera: Plutellidae). Neotropical Entomology, 35: 241-245.
Simões, R.A., Letícia, R.G., Bento, J.M.S., Solter, L.F., and Delalibera, I. 2012. Biological and behavioral parameters of the parasitoid Cotesia flavipes (Hymenoptera: Braconidae) are altered by the pathogen Nosema sp. (Microsporidia: Nosematidae). Biological Control, 63: 164-171.

Strand, M.R. 2008. The insect cellular immune response. Insect Science, 15: 1-14.

Vargas, E.L., Pereira, F.F., Calado, V.R.F., Glaeser, D.F., Rodrigues, B.A.C., and Silva, N.V. 2014. Densidade de fêmeas de Trichospilus diatraeae (Hymenoptera: Eulophidae) por pupa de Diatraea saccharalis (Lepidoptera: Crambidae). Sitientibus série Ciências Biológicas, 13: 1-7.

Vargas, E.L., Pereira, F.F., Tavares, M.T., and Pastori, P.L. 2011. Record of Tetrastichus howardi (Hymenoptera: Eulophidae) parasitizing Diatraea sp. (Lepidoptera: Crambidae) in sugar cane crop in Brazil. Entomotropica, 26: 143-146. 